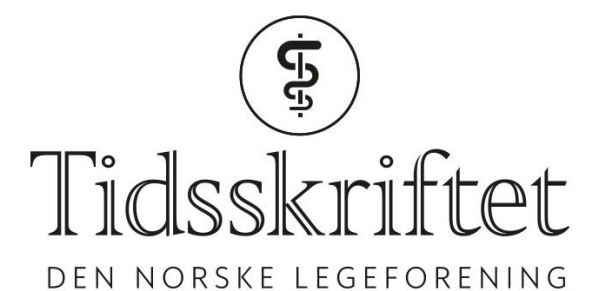

DEN NORSKE LEGEFORENING

\title{
Kvinnen som fødte i søvne
}

TIDLIGERE I TIDSSKRIFTET

JULIE DIDRIKSEN

Tidsskriftet

På 1940-tallet ble en gravid pasient lagt inn på sykehus. Hun var midt i tyveårene, sunn, frisk og førstegangsfødende. Svangerskapet hadde vært uproblematisk, helt uten sykedager eller så mye som litt kvalme. Selve fødselen var riktignok litt utenom det vanlige. Under følger artikkelen, som sto på trykk i Tidsskriftets utgave nr. 4/1945 (Tidsskr Nor Lægeforen 1945; 65: 121).

\section{NORMAL FØRSTE GANGS FØDSEL UNDER TILSYNELATENDE NORMAL S $\emptyset \mathrm{VN}$}

\section{AV H. FR. HARBITZ}

Følgende kasus synes å måtte påregne noen interesse:

(...) Hun har vært frisk under hele svangerskapet, ikke syk en dag, ikke kastet opp. Hun har gått til kontroll hos læge som intet galt har funnet, spesielt ikke albumin eller blodtrykksforhøyelse.

Hun innkom (...) om formiddagen kl.10 med svake rier, vannet stod. Riene tiltok litt utover dagen, var helt regelmessige. Kl. 22, like etter at vannet var gått, ble riene sterkere. Kl. 3 om morgenen (...) ringte hun, idet hun trodde fødselen skulle foregå. Man kunne da kjenne hodet over symfysen. Jordmoren som hadde sitt værelse ved siden av, hørte litt ynking et par timer, men så ble det helt stille omkring kl. 5. Pasienten sov rolig. Nattevakten var stadig inne og morgenstellet begynte på avdelingen, og pasienten sov stadig. Da nattevakten kom inn kl. 6,15 oppdaget hun at barnet delvis var født. Jordmoren ble straks tilkalt og fant at barnets hode og kroppen var født, mens benene var i ferd med å fødes. Moren hadde såvidt slått øynene opp, hadde satt en fot over barnet, men var helt uten forståelse eller fornemmelse av hva som foregikk. Barnet (...) skrek straks. Vekt 3040 g, lengde $50 \mathrm{~cm}$, hodets omkrets $34 \mathrm{~cm}$. Der var ingen perinealruptur. Placenta kom spontant etter $15 \mathrm{~min}$. ved et lett trykk, hel med hele hinner.

Moren våknet etter hvert, men noe langsomt og tregt og var ved 7,30-tiden godt våken. På morgenvisitten var hun helt klar og orientert og virket normal i enhver henseende. Hun hadde ikke fått noen sovemedisin og intet medikament hverken før fødselen eller tidligere. Utover dagen var hun litt døsig og søvnig. Den påfølgende natt sov hun hele natten, en vanlig naturlig søvn.

Urinundersøkelse ved innkomsten før fødselen viste klar, sur urin, Vogel 1, sp. v. 1015, alb.-, $\mathrm{KOH}$-, sukker-, blod-. R. R. om morgenen kort etter fødselen 130/90. Barselsengen var feberfri og ellers ukomplisert.

Hun stod opp etter 8 dager, urin alb.-. Utskrevet 9. dag etter fødselen. 
Moren hadde hverken i svangerskapet eller i barselsengen hatt noe tegn på intoksikasjon, spesielt ikke hodepine, synsforstyrrelser eller ødemer. (...) Hun har alltid vært normal, ingen tidligere absenser, ingen epilepsi, ingen sykelig belastning av noen art.

Såvidt man kan bedømme av det foreliggende tilfelle har den helt normale fødsel foregått i en tilsynelatende normal søvntilstand. Dette vil naturligvis alltid kunne diskuteres; men det er i dette tilfelle intet holdepunkt for at det skulle ha foreligget noen omtåket tilstand som følge av en svangerskapsintoksikasjon eller annen sykdom. Fødselsveiene synes å ha vært meget ettergivelige, idet der ikke oppstod noen ruptur, hvilket jo er relativt sjelden hos en førstegangsfødende.

Rettsmedisinsk synes tilfellet å ha betydning fordi en slik fødsel kan skje i det hele tatt, og da er det heller intet i veien for at moren ubevisst kunne ha ombragt sitt barn.

Publisert: 8. november 2018. Tidsskr Nor Legeforen. DOI:10.4045/tidsskr.18.0731

(C) Tidsskrift for Den norske legeforening 2020. Lastet ned fra tidsskriftet.no 